\title{
The Impact of Merger and Acquisition on Investor Reaction and Acquirer Firm's Financial Performance in Technology Firms
}

\author{
Juniarti Juniarti $^{1 *}$, Yosephine Kurnia Anggita ${ }^{1}$ Angeline Angeline ${ }^{1}$ \\ ${ }^{1}$ Department of Business Accounting, Petra Christian University, Surabaya, Indonesia \\ "Corresponding author. Email: d12180037@john.petra.ac.id
}

\begin{abstract}
Nowadays, technology sectors are continuously developing through merger and acquisition activities. Previous literature found that mergers and acquisitions affect both investor reaction and firm's financial performance on separate studies. However, there were contradictory results between the positive and negative impacts. Therefore, this study aims to simultaneously search the impact of mergers and acquisitions on investor reaction and acquirer firm's financial performance. The technology sector is chosen in this study as there are fewer studies regarding investor reaction and financial performance in this sector. The investor reaction is measured using Cumulative Abnormal Return (CAR). Whereas an acquirer firm's financial performance is measured using Return on Asset (ROA). This study used companies' data that have merger and acquisition transactions from 2015 through 2019. To be included as a sample, the company must have a headquarter in Asia and must be a public company in the technology sector. The data analyzing method used in this study is Ordinary Least Square (OLS). The findings suggest that mergers and acquisitions have a positive and statistically significant impact on investor reaction in the short term. However, the positive impact on the acquirer firm's financial performance is not statistically significant. Due to restrictions in accessing internal company's data, this study could only be conducted on public companies. This study contributes to previous literature related to investor reaction and firm's performance as both of them are rarely tested simultaneously in previous studies especially in the technology sector.
\end{abstract}

Keywords: Merger and acquisition, Investor reaction, Financial performance.

\section{INTRODUCTION}

The revolution in information and telecommunications led to an increase in global merger and acquisition (M\&A) activity in the technology sector in the 21 st century. This led to significant development in the technology sector [1]Along with the current use of technology that continues to increase, this sector is also experiencing significant development to meet the demands of society. This study focuses on the technology sector because, in this sector, M\&A has a more positive effect on company performance. After all, companies in this sector can implement newly acquired technologies quicker [1][2][3][4]. This study does not only aim to find evidence related to investor reaction to corporate action through mergers and acquisitions carried out by companies in the technology sector on a short-term basis, but also looks at the firm's performance after mergers and acquisitions.
Several researchers have conducted research on the effect of mergers and acquisitions on investors which shows that there is a positive effect on stock prices after the announcement of the M\&A $[5][6][7][8][9][10]$. However, contrary to the findings above, several researchers [14][15][16] found a negative effect on investor reaction to mergers and acquisitions.

Previous research has also tested the effect of merger activities on a company's financial performance [4][5][6][11][12][13][14].The findings show that there is a positive effect on M\&A activity announcement on a company's performance [2][12] Nevertheless, these results are not solid as many other researchers have found that M\&A activities negatively affect financial performance [4][11][15] [16][17]Meanwhile, few studies found no effect between them [18][14]. 
The facts on the field show differences in investor reaction and firm's financial performance as measured by Return on Assets (ROA) in four companies operating in the technology sector in the United States and Asia. The phenomena in the field show differences in investor reaction to $M \& A$ both in the long term at the event window eleven months before and eleven months after the announcement, as well as in the short term at the event window ten days before and ten days after the announcement with firm's financial performance (ROA).

There is a phenomenon of acquisitions made by two companies in the United States are Intel and NVIDIA. As seen in Figure 1 and Figure 2, the two companies experienced a positive reaction from acquisitions, either in the short-term or long-term, which positively, the stock prices of the two companies increased after the merger even though the company's ROA decreased. This situation is consistent with previous studies, which found that mergers and acquisitions received a positive reaction from investors [19][20][21][22][23][24][25].

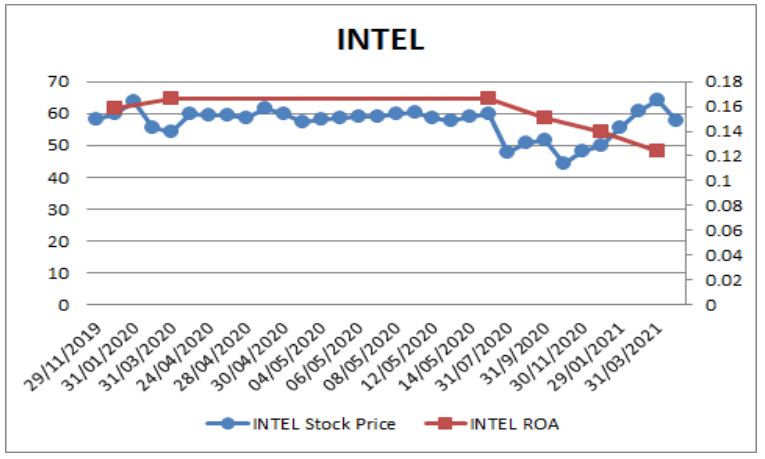

Figure 1 Intel's Investor Reaction and Financial performance

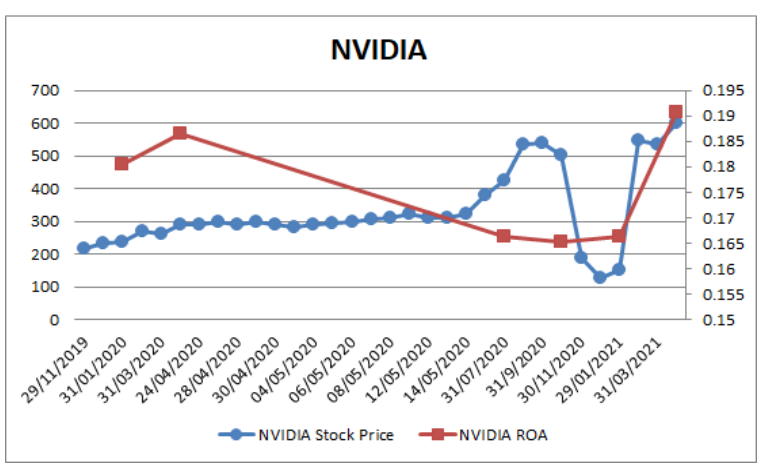

Figure 2 NVIDIA's Investor Reaction and Financial performance

However, the reaction of the two companies is different from the reaction that occurred in the two companies in Asia which are PT Anabatic Technologies Tbk. and Sony Group Corp. As can be seen in Figure 3 and Figure 4, the two companies experienced negative reactions from investors, both short-term and long-term.
However, there is an increase in ROA at PT Anabatic Technologies Tbk. on a short-term basis and with Sony Group Corp on a short-term and long-term basis. This case is consistent with the previous studies, which found that mergers and acquisitions received a negative reaction from investors [14][15][16].

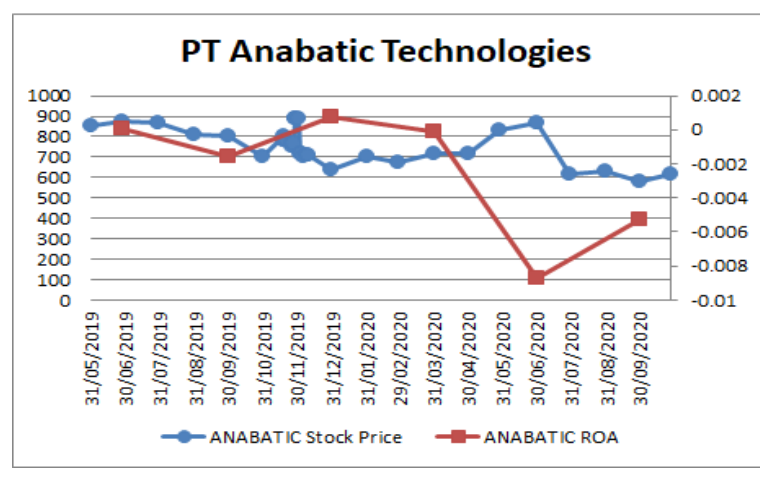

Figure 3 PT Anabatic Technologies's Investor Reaction and Financial performance

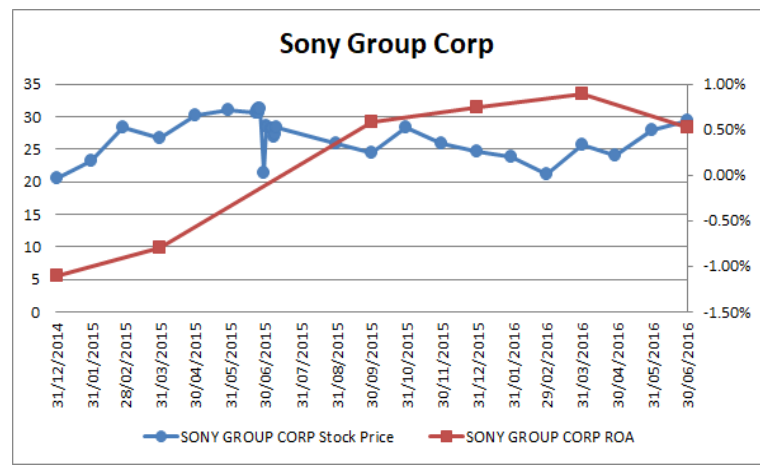

Figure 4 Sony Group Corp's Investor Reaction and Financial performance

Differences in research focus can cause this inconsistency. The difference of facts in the field related to investor reaction and financial performance on merger and acquisition activities in the case above is in line with several empirical findings as there are differences in reaction to M\&A activities in different countries. Research conducted in several countries such as China, the US, UK, and Hong Kong showed that M\&A was responded positively by investors [26] [22] Reference [23] [18] [16][7][6] found positive results that focus on transactions in several countries in Asia, such as Hong Kong, China, Taiwan, Singapore, South Korea, and Japan. Meanwhile, research that found negative investor reactions to mergers and acquisitions focused on M\&A transactions in Pakistan [27] Spain [15] and Turkey [11].Therefore, from previous research, it can be concluded that transactions conducted in 
developed countries receive a positive reaction from investors.

Investors appreciated M\&A activities in several previous empirical studies because they signaled the company's promising prospects in the future, despite the results that were not yet entirely conclusive. The phenomenon in the field is in line, especially in developed countries, where investors respond positively to M\&A activities. In the long term, M\&A activities should have an impact on financial performance.

This research could contribute to previous financial literature. As this research comprehensively examines the effect of M\&A on investor reaction and financial performance, this research could provide additional empirical evidence regarding the benefits of M\&A activities for investors.

The following are the remaining sections of the paper; section 2 provides the literature review and hypothesis development, section 3 shows the data and the research methods, section 4 presents the analysis of the findings, and section 5 concludes and presents the study's limitations.

\section{LITERATURE REVIEW \& HYPOTHESIS DEVELOPMENT}

\subsection{Signaling Theory}

Signaling theory explains how incomplete and asymmetrical information is responded to by decisionmakers or investors [22]. This theory has three main elements, the first is signallers which is the company that conducts mergers and acquisitions transactions. The second element is receivers which are the investors who do not have information due to information asymmetries but want to obtain this information to assess the firm's actual value accurately. The third element is the signal which is the information conveyed by the company as signallers to investors as the receiver of the information so that investors can capture the intention of the management of companies that conduct mergers and acquisitions and can make the right decisions on buying and selling stock in the stock market. In previous research [11], signaling theory was used to explain investor reaction to M\&A announcements. The expectation is that the investors will give a positive reaction if investors interpret the M\&A announcement as an optimistic belief in the future. If the information submitted by the acquiring firm's management is clear and the investor has a high confidence level for the information, then the information will be reflected in the investor's reaction. With the signaling theory, this research can predict investor reaction to $\mathrm{M} \& \mathrm{~A}$ announcements made by acquirer firms. In this study, the signal is an M\&A announcement made by an acquirer firm that can affect the stock market reaction or investor reaction to the transaction.

\subsection{Merger and acquisition}

Mergers and acquisitions are one of the fastest strategies to increase company growth by expanding the company's business [18]. Based on previous research, mergers and acquisitions can affect investor reactions both to the target firm and to the acquiring firm [28]. In acquiring firms, conducting M\&A transactions can cause a positive influence as it will create synergy [5] and the acquiring firm's size will increase [9]. Furthermore, M\&A will have a negative effect if investors perceive that the M\&A transaction does not provide potential profits [14] or very little information is publicly available [16].

Previous studies have also found that mergers and acquisitions can affect the target and acquirer firm's financial performance [29] In the technology sector, M\&A has a positive reaction to acquirer firms' financial performance compared to other sectors because companies can apply newly acquired technology quicker [2] Mergers and acquisitions can positively affect a firm's financial performance [7][8]After conducting M\&A, companies in the growth stage will experience increased performance due to the increasing industry concentration and company scale, expand to new markets as well as acquire new knowledge and resources. Mergers and acquisitions can also reduce financial performance due to the company's lack of experience and ability in conducting M\&A and the lack of synergy after conducting M\&A transactions [20][22].

\subsection{Investor Reaction}

Investor reaction is a form of reaction given by the investor to an action taken by the company [15].If the information provided by the company has guaranteed quality, then the investor's reaction to the information will be faster. Generally, the measurement of investor reaction uses Abnormal Returns (AR), which is the difference between the actual returns and the expected returns of the stock. Meanwhile, Cumulative Abnormal Returns (CARs) will be obtained by adding all abnormal returns received by the company on an event window [14]. In this study, the model used to test investor reaction is the Market Model as this model also considers the existing risk $(\beta)$ in addition to the impact on the market [9].

Previous research that focused on acquiring firms found that after the company conducted mergers and acquisitions, the company experienced 
a positive impact on the capital market reaction in the long-term [5][6] and short-term [5][6][7][8][9][10][11]. In the long-term, this study uses the event window 6,12 , 24, and 36 months after the M\&A announcement [5] and in the event window three years after the M\&A announcement using buy-in-and-hold abnormal returns (BHAR) [6]. The positive reaction is also found on short terms, on the 1-day, 3-day, 5-day, and 11-day event window, on 1-day and 2-day event window [6], as well as on 3-days, 6-days, 21-days, and 41-day event window [7] which is measured using cumulative abnormal returns (CARs). Moreover, in the event window 50-days to 2 days before, 1-day before, and the day when the company made the announcement, as well as 1-day and 50-days after the M\&A announcement, which is measured using cumulative above abnormal returns (CAARs) [13]. Some researchers also found positive results with the same measurement in the event window 26-days before and 26days after the announcement [8] and in the event window 60-days [9] after the M\&A announcement. This study also found positive reaction by investors in the 1-day, 2days, and 5-day event windows [11] as well as in the 40day window event [12] after the M\&A announcement which is measured using Abnormal Return (AR). In addition, the previous studies found an insignificant positive effect [10]. The researcher conducted the study on event windows 1-day, 2-days, 5-days, and 15-days after the M\&A announcement which is measured using cumulative above abnormal returns (CAARs).

Reference [5] found that factors positively affecting the abnormal returns obtained by acquirer's firms are the synergy obtained by conducting mergers and acquisitions. Institutional and long-term institutional investors can also affect investor reaction as they can monitor companies effectively [7]. Reference [6] found several factors that can influence the abnormal returns obtained by acquirer's firms, such as firm ownership and payment methods. State-owned enterprises (SOEs) can have a positive influence due to the support received from the government. Therefore, the company's business scale and performance management can improve as the resources can be used optimally. Payment methods, such as cash in transactions, can increase the transaction value [6][8]. On the other hand, target size can also affect investor reaction, where the bigger the target size, the greater the possibility to create more synergies and increase shareholder value [8][10].

\subsection{Acquirer firm's financial performance}

The company's financial performance can be measured using several measurements such as profitability ratio, liquidity ratio, and solvency ratio [29][20][21]. In previous studies, one of the profitability ratios, which is ROA, was generally used to measure a firm's financial performance [2][15][19][29]. Therefore, this study will focus on and use the company's profitability ratio which is $\mathrm{ROA}$, to measure the firm's financial performance.

Several studies found that there is a positive influence on the company's financial performance after the company makes M\&A announcements, both in the research that focuses on acquirer firms [2][17] or in the research that focuses on target firms [25][26][27][28]. Previous research has found that the performance of acquirer firms has increased in the year of conducting M\&A announcements until the next two years [2] which is measured by Return on Assets (ROA). An increase in the performance of acquirer firms was also found in previous studies, in the period one year after the merger which is measured by sales, productivity, tangible and intangible assets [17].

Meanwhile, several researchers found a negative effect [4][15][18][19][29]. Researchers found that the company's ROA decreased after conducting M\&A [15][19][29]. The company's operating performance also decreased within three years after conducting M\&A [18]. Reference [1] found that in the short term, the company's Enterprise Value Multiple (EV/EBITDA) has decreased after mergers and acquisitions.

Contrary to the findings above, some studies found that mergers and acquisitions are not significant both on the target firm [27] or the acquiring firm [20][21]. Reference [20] found that overall, in the three years before and three years after M\&A, the M\&A transactions did not significantly affect the acquirer's firm profitability, liquidity, and firm's leverage position even though it affected the quick ratio negatively. In addition, at the same period, other researchers also found that after conducting $\mathrm{M} \& \mathrm{~A}$, the increase in liquidity ratio and decrease in the solvency acquiring firm was not significant [21].

\subsection{Hypothesis Development}

Following signaling theory, acquirer firms will get a positive reaction from investors [22]. This situation happens as the investors can capture this information and make transaction decisions on the right stocks market with the signal given by the acquirer firm in the form of merger and acquisition announcements. If the information is clear, then the information will be reflected in the stock market, assuming that investors have a high confidence level and assess the M\&A transactions that the company has conducted as an optimistic belief in the future [11]. This finding is also consistent with previous research, which found that after conducting M\&A, investor confidence increased and caused the company's market value to surge in 
the short term [9]. In addition, the synergy generated through mergers and acquisitions transactions can lead to an increase in expected returns, and the capital market reaction can be positive [5].

In previous studies, firm size, as well as the sector of the acquirer and acquired firms, are among the things that affect the risk received by investors [10]. If the acquirer company has a larger size than the target company, then the investor reaction of the acquirer company will have a low probability of getting a negative impact from the M\&A transaction. By having a low risk, the market will see that the M\&A can increase shareholder value. Therefore, the share price of companies in the sector that conduct M\&A could increase.

Empirical evidence proves that with the company's mergers and acquisitions, the company's stock price can increase in the short term, showing a positive reaction from the investors. In the studies conducted using the measurement of cumulative abnormal returns (CAR), investors have a positive reaction, which is reflected in the increase in stock prices of acquirer firms [5][6][7]. Following the approach based on the stock market and previous research, this study will use the measurement of cumulative abnormal returns (CAR) and will be carried out on a short-term basis so that the results obtained can be more accurate and more reliable [24]. Therefore, the developed hypothesis is:

\section{$\mathrm{H}_{1}$ : Merger and Acquisition positively affect investor's reactions in the short term}

Previous research has found that mergers and acquisitions can positively affect a firm's financial performance [17][2]. However, compared to studies that find a positive effect, more studies find that there is a negative effect on the firm's financial performance after conducting M\&A [4][15][18][19][29]. Previous research found that the decline in company performance could be due to the company's lack of experience and ability to conduct M\&A [4]. In addition, adverse effects can also occur if the purpose of conducting M\&A transactions is not to improve the firm's financial performance but to do a risk reduction. Another study found that adverse effects could occur due to a lack of synergy after conducting M\&A transactions [29]. To achieve synergy, acquiring firms need to use existing resources appropriately, evaluate target firms, and estimate prospects accurately.

Furthermore, previous research found that internal factors from the acquirer firm itself can affect the effect of M\&A transactions on its financial performance, which is the firm size [2][4]. The larger the acquiring firm's size, the more extensive the resources owned by the firm. In addition, firm age is also a factor influencing it [2]. The older a firm is, the more positively the firm's financial performance will be affected after mergers and acquisitions than the younger firm [2]. This happened because older firms can invest more resources in mergers and acquisitions. The company's leverage can also have an effect, where the higher the leverage, the more significant the financial problem so that the profitability obtained by the company will decrease [4].

Several researchers have conducted the research using ROA as the measurement and found that by conducting M\&A, there will be a negative effect on the company where the acquirer firm's financial performance may experience a decline [15][19][29]. Thus, this study will focus on the profitability ratio, which is the company's ROA, to determine the firm's financial performance. Thus, this study can measure how efficient management is in using assets owned by the company [29]. Therefore, the hypotheses developed are:

$\mathrm{H}_{2}$ : Merger and Acquisition negatively affect acquirer firm's financial performance

\section{METHOD}

\subsection{Research Sample}

This study used Bloomberg to obtain mergers and acquisitions transactions and the company's financial statements. Meanwhile, this study used Yahoo Finance to obtain stock price information. Transactions were selected as a sample according to the following criteria:

1) Companies must be registered to the Global Industry Classification Standard (GICS) under the name of the Information Technology sector and conduct merger and acquisition transactions in 2015-2019.

2) The acquirer firm must have a headquarter in Asia and must be a public company

3) Merger and acquisition transactions must be complete.

4) Acquirer firm and stock price data must be available on Yahoo Finance.

5) Financial statements of the acquirer firm must be available one year before one year after the event date.

If the acquirer firm conduct other mergers and acquisitions transactions in the period one year before and one year after the event date, then those transactions will be removed from the sample. The sample in this study can be seen in the Table 1.

\subsection{Model of Analysis}

In this study, several control variables were tested simultaneously which are firm size, firm age, and leverage. The bigger the acquirer's firm size 
compared to the target company, the risk that the investor received would be lower [10] and the resource that the acquirer firm has would be bigger [23] [18] [16][7][6] The older the firm's ages, the more the resource that could be invested in the transaction will be more enormous [2]. Companies that have a higher level of leverage show that the companies have a higher financial problem [4]. To understand the effect of firm size, firm age, and leverage on the relation between investor reaction and firm's financial performance with merger and acquisition announcement, those three variables will be used in this study as the control variables.

The software used in this study to test the hypothesis is SPSS. Acquirer firm's financial performance as the dependent variable and control variable is lagged as the previous year performance (t-1) may affect the performance on that year $(\mathrm{t})$ [4]. Furthermore, to analyze the internal factor of the firm, the control variables are regressed simultaneously with the independent variable in the model.

The research model for this study to test hypothesis 1 is as follow:

$$
\begin{aligned}
\mathrm{CAR}_{\mathrm{i}, \mathrm{t}}= & \alpha_{0}+\alpha_{1} \mathrm{MA}_{\mathrm{it}}+\alpha_{2} \mathrm{SIZE}_{\mathrm{it}-1}+\alpha_{3} \mathrm{AGE}_{\mathrm{it}-1}+ \\
& \alpha_{4} \mathrm{LEV}_{\mathrm{it}-1}+\varepsilon_{\mathrm{it}}
\end{aligned}
$$

where:

$\mathrm{CAR}_{\mathrm{i}, \mathrm{t}}=$ Cumulative Abnormal Return of firm $\mathrm{i}$ on time $\mathrm{t}$ $\varepsilon_{\mathrm{it}}=$ Error with the mean of zero

The research model for this study to test hypothesis 2 is as follow:

$$
\begin{aligned}
\operatorname{ROA}_{\mathrm{i}, \mathrm{t}}= & \beta_{0}+\beta_{1} \mathrm{MA}_{\mathrm{it}}+\beta_{2} \operatorname{SIZE}_{\mathrm{it}-1}+\beta_{3} \mathrm{AGE}_{\mathrm{it}-1}+ \\
& \beta_{4} \mathrm{LEV}_{\mathrm{it}-1}+\varepsilon_{\mathrm{it}}
\end{aligned}
$$

where:

$\mathrm{ROA}_{\mathrm{i}, \mathrm{t}}=$ Financial performance of firm $\mathrm{i}$ on time $\mathrm{t}$

$\varepsilon_{\mathrm{it}}=$ Error with the mean of zero

\subsection{Variables Operationalization}

\subsubsection{Dependent Variables}

\subsubsection{Investor Reaction}

To assess the effect of mergers and acquisitions on investors, this study will measure abnormal returns from mergers and acquisitions transactions obtained by investors in the short term around the M\&A announcement. By using the CAR measurement, the results obtained will provide helpful information to the company regarding the abnormal returns that the company will obtain. Thus, if there is a significant abnormal return around the M\&A announcement, this situation indicates that the transaction influences shareholder wealth and has information content [15].

Based on previous research, there are several steps in calculating abnormal returns. The first step in this analysis is to determine the sample of firms included in the analysis. This study selected companies in the technology sector that conducted M\&A transactions between 2015 and 2019 that matched the criteria above as samples.

The second step is to determine the event window to use. In short terms, this research will use the 21-day event window, which is ten days before the event day and ten days after the event day $(-10$, +10 ). These event window lengths used in this study to capture the merger and acquisition announcement effect accurately as it takes longer than one day for the announcement to be reflected on the stock market [10].

The third step is to predict the return obtained in the event window, which is unaffected by any event. The model used in this study is the market model to determine the expected return (ER). The dependent variable and security returns are regressed to the percentage difference in the market index and using the stock price data for 120 days on trading days. The market model used in this study can be expressed by the following linear time-series model:

$\mathrm{R}_{\mathrm{it}}=\alpha_{\mathrm{it}}+\beta_{\mathrm{it}}, \mathrm{R}_{\mathrm{mt}}+\varepsilon_{\mathrm{it}}$

where:

$\mathrm{R}_{\mathrm{it}}=$ Return on the security of firm $\mathrm{i}$ on day $\mathrm{t}$

$\alpha_{\text {it}}, \beta$ it $=$ market model parameter

$\mathrm{R}_{\mathrm{mt}}=$ Return on a market portfolio

$\varepsilon_{\text {it }}=$ Error with the mean of zero over the regression period

The fourth step is to calculate the abnormal return, where the abnormal return itself is the difference between the actual and the predicted return from the market model. If the value of Abnormal return $\left(\mathrm{AR}_{\mathrm{it}}\right)$ is not zero, this indicates that the M\&A announcement affects the company's performance. This value can be obtained through:

$\mathrm{AR}_{\mathrm{it}}=\mathrm{R}_{\mathrm{it}}-\left(\alpha_{\mathrm{it}}-\beta_{\mathrm{it}}, \mathrm{R}_{\mathrm{mt}}\right)$

Cumulative abnormal return (CAR) on several holding periods from day $\mathrm{t} 1$ today $\mathrm{t} 2$ is calculated using the formula below:

$\mathrm{CAR}_{\mathrm{t} 1, \mathrm{t} 2}=\sum_{t=t 1}^{t 2} \mathrm{AR}_{\mathrm{it}}$ 
where:

$\mathrm{AR}_{\mathrm{it}}=\mathrm{Abnormal}$ return on the security of firm $\mathrm{i}$ on day $\mathrm{t}$

\subsubsection{Acquirer firm's financial performance}

The impact of mergers and acquisitions on a firm's financial performance is measured by the firm's Return on Assets (ROA) which is obtained through:

Return on Assets $(R O A)=\frac{\text { Net Income }}{\text { Total Assets }}$

This study will compare the difference of the ROA from each company that has done merger and acquisition transactions that are included in the sample from one year before the announcement $(\mathrm{t}-1)$ to 1 year after the announcement $(t+1)$. Then, the Ordinary Least Square (OLS) regression analysis will be used to analyze the impact of the other variables on merger and acquisition to acquirer firm's financial performance before and after the announcement.

\subsubsection{Independent Variables}

\subsubsection{Merger and Acquisition (MA)}

Transactions that are used in this study comprise all three types of M\&A that were done by the company. A dummy variable is used to measure the company that did merger and acquisition transactions where the firm that conducts $M \& A$ transactions will be given the value of 1 whereas the firm that does not conduct M\&A transactions will be given the value of 0 [20].

\subsubsection{Control Variables}

\subsubsection{Firm Size (SIZE)}

Firm Size is measured by the Total Asset of the acquirer's firm [2].

\subsubsection{Firm Age (AGE)}

Firm Age is measured by calculating the years the acquirer's firm has gone IPO until the event date [20].

\subsubsection{Leverage (LEV)}

Leverage is the ratio of Total Debt to Total Asset [6].

\section{RESULTS \& DISCUSSION}

Based on the Global Industry Classification Standard (GICS), there are 3757 companies in the Information Technology sector. Based on Bloomberg, there are 390 companies out of 3757 companies conducting Merger and Acquisition transactions. However, there are only 226 companies with complete data. The control sample used in this study is companies that do not conduct merger and acquisition transactions in the 20152019 period with comparable firm sizes in the same industry group. Thus, the final number of control samples with complete data is 121 companies. Based on the sample criteria above, the sample used in this study is 356 observations to examine investor reactions and 1068 observations to examine firm's financial performance.

\subsection{Hypothesis Testing}

\subsubsection{Impact of Merger and Acquisition on Investor Reaction}

In this study, the data analysis method used was a regression with the Ordinary Least Square (OLS) technique by testing heteroscedasticity, normality, and multicollinearity on the sample used.

In Table 2, it can be seen that CAR $(-10,+10)$ has a range from -0.7947 to 0.7903 . Firm Size has a value with a range of 4596905.01 to 32884015132 with an average of 1417569313. Firm Age has a value with a range of 0 to 70 with an average of 13.4. At the same time, Leverage has a value of 0 to 0.79593 with an average of 0.135596 . Due to the large amount of data in this study, the KolmogorovSmirnov test will be used to test the normality of the residuals of the OLS regression. The result indicates the CAR $(-10,+10)$ has a value smaller than 0.05 , which indicates that the CAR does not have an even distribution of data. Therefore, to have normally distributed data, the data is transformed. The data with missing values were eliminated from the sample. Therefore, the final sample used in this study is 175 observations. In multicollinearity testing, all variables have Variance Inflation Factors (VIF) values below 10, which means that all variables do not have problems in multicollinearity. Furthermore, based on the scatter plot, there is no heteroscedasticity in the data. 
Table 1. Sample

\begin{tabular}{|c|c|c|}
\hline Sample & Frequency & Percentage \\
\hline M\&A & 116 & $66,29 \%$ \\
\hline Non-M\&A & 59 & $33,71 \%$ \\
\hline Total & 175 & $100 \%$ \\
\hline
\end{tabular}

Table 2. Variable Descriptive Analysis

\begin{tabular}{|c|c|c|c|c|}
\hline Variable & Mean & S.D. & Min & Max \\
\hline CAR & 0.006345 & 0.1337439 & -0.7947 & 32884015132 \\
\hline SIZE & 1417569313 & 4174893912 & 4596905.01 & 70 \\
\hline AGE & 13.4 & 11.297 & 0 & 0.79593 \\
\hline LEV & 0.135596 & 0.1454469 & 0 & 0.793 \\
\hline
\end{tabular}

Table 3. Hypothesis Testing

\begin{tabular}{|l|c|c|l|}
\hline & Standardized Coefficients & t & \multicolumn{1}{c|}{ Sig. } \\
\hline (Constant) & & -13.092 & $<.001$ *** \\
\hline M\&A & 0.171 & 2.204 & 0.029 ** \\
\hline SIZE & 0.012 & 0.124 & 0.902 \\
\hline AGE & -0.147 & -1.517 & 0.131 \\
\hline LEV & -0.057 & -0.759 & 0.449 \\
\hline Adjusted R Square & & 0.043 & \\
\hline F & & 2.971 & \\
\hline Sig. & & 0.021 & \\
\hline
\end{tabular}

$* * * 0.01$ significance level, $* * 0.05$ significance level, $* 0.1$ significance level

In Table 3, we can see a significant and positive effect between Merger and Acquisition on investor reaction which is measured by CAR in the event window $(-10$, +10 ), which can be seen in the positive coefficient value. Furthermore, there is an insignificant positive relationship between the dependent variable, CAR, and Firm Size, which can be seen in Table 3. As seen in Table 3, there is an insignificant and negative relationship between the dependent variable, CAR, and Firm Age as well as Leverage, indicated by the negative coefficient value in the event windows. At the same time, the Adjusted $\mathrm{R}^{2}$ obtained in Table 3 is $4.3 \%$, which means that the independent variable's ability to influence CAR is $4.3 \%$. This case shows that sequentially there are $95.7 \%$, other factors not discussed in this study that can affect CAR after conducting merger and acquisition transactions.

\subsubsection{Impact of Merger and Acquisition on Acquirer Firm's Financial Performance}

To examine the acquirer firm's financial performance, the data analysis method used in this study is the regression with the Ordinary Least Square (OLS) technique by testing heteroscedasticity, normality, and multicollinearity on data that matches the sample used. To compare the investor reaction and firm's financial performance, the sample used to test the financial performance is 525 observations in Table 4. 
In Table 5, it can be seen that ROA has a range from -1.8245 to 8.9069 . Firm Size has a value with a range of 3055224.76 to 32884015132 with an average of 1655781031. Firm Age has a value with a range of 0 to 70 with an average of 13.2629. At the same time, Leverage has a value of 0 to 1.11 with an average of 0.1429 . Due to the large amount of data in this study, the Kolmogorov-Smirnov test will be used to test the normality of the residuals of the OLS regression. The result indicates that ROA has a value smaller than 0.05 , which indicates that ROA does not have an even distribution of data. The solution is that if there are outliers in the company's data, then the data are eliminated from the sample. Therefore, the final sample used in this study is 480 observations. However, after doing the normality test again, the value obtained is still smaller than 0.05. Apart from these results, following the Central Limit Theorem (CLT) theory, it can be concluded that the sample is distributed normally as the sample used in this study is large. In multicollinearity testing, all variables have Variance Inflation Factors (VIF) values below 10 , which means that all variables do not have problems in multicollinearity. Furthermore, based on the scatter plot, there is no heteroscedasticity in the data.

Table 4. Sample

\begin{tabular}{|l|c|c|}
\hline Sample & Frequency & Percentage \\
\hline M\&A & 321 & $66.88 \%$ \\
\hline Non-M\&A & 159 & $33.13 \%$ \\
\hline Total & 480 & $100 \%$ \\
\hline
\end{tabular}

Table 5. Descriptive Analysis

\begin{tabular}{|c|c|c|c|c|}
\hline Variable & Mean & S.D. & Min & Max \\
\hline ROA & 0.065844 & 0.4294023 & -1.8245 & 32884015132 \\
\hline SIZE & 1655781031 & 4427103239 & 3055224.76 & 70 \\
\hline AGE & 13.2629 & 11.6514 & 0 & 1.11 \\
\hline LEV & 0.1429 & 0.14539 & 0 & 0 \\
\hline
\end{tabular}

Table 6. Hypothesis Testing

\begin{tabular}{|c|c|c|c|}
\hline & Standardized Coefficients & $\mathrm{t}$ & Sig. \\
\hline (Constant) & & 10.687 & $<.001 * \star \star$ \\
\hline$M \& A$ & 0.06 & 1.395 & 0.164 \\
\hline SIZE & -0.053 & -1.008 & 0.314 \\
\hline AGE & -0.051 & -0.963 & 0.336 \\
\hline LEV & -0.414 & -9.95 & $<.001^{* * *}$ \\
\hline Adjusted R Square & \multicolumn{3}{|c|}{0.186} \\
\hline$F$ & \multicolumn{3}{|c|}{28.34} \\
\hline Sig. & \multicolumn{3}{|c|}{$<.001$} \\
\hline
\end{tabular}

$* * * 0.01$ significance level, $* * 0.05$ significance level, $* 0.1$ significance level 
In Table 6, it can be seen that there is an insignificant and positive effect between Merger and Acquisition on the acquirer firm's financial performance, which can be seen in the positive coefficient value. Furthermore, there is a negative and insignificant relationship between the dependent variable, ROA with Firm Size and Firm Age. Meanwhile, there is a negative and significant relationship between ROA and Leverage. While the Adjusted $\mathrm{R}^{2}$ obtained is $18.6 \%$, which means that the ability of the independent variable in influencing ROA is $18.6 \%$. This shows that $81.4 \%$ of other factors not discussed in this study can affect ROA after conducting Merger and acquisition transactions

\subsection{Discussion}

Based on Table 3 in this study, it can be concluded that Mergers and Acquisitions have a significant effect on investor reaction in the short term, which means that $\mathrm{H} 1$ is accepted. This is due to the positive effect on CAR with the event window $(-10,+10)$. This shows that the event window used can capture the effects of the merger and acquisition announcement accurately and it could be seen that the announcement is reflected on the stock price [10]. This also shows that mergers and acquisitions could increase the company's shareholder wealth after the announcement [5]. This finding is consistent with previous research with a positive and significant effect on investor reaction to mergers and acquisitions in the shortterm [5][6][7][8][9][11]. However, it contradicts several research that found a negative effect on investor reaction [14][15][16]. It can be seen that in Table 3 there is a positive relationship between CAR and Firm Size but it is not statistically significant. There is a negative relationship between CAR and Firm Age as well as Leverage. However, the effect is not statistically significant.

Based on Table 6 in this study, it can be concluded that Mergers and Acquisitions have an insignificant and positive effect on the acquirer firm's financial performance, which means that $\mathrm{H} 2$ is rejected. In this study, a positive but insignificant effect can be caused by the ability of the independent variable to affect ROA is $18.6 \%$, while there are $81.4 \%$ other factors not discussed in this study that can affect ROA after conducting Merger and acquisition transactions. The results of this study are different from previous studies and can be caused by differences in the period used in the study. The period used is one year before and one year after the event day. In general, previous research related to the effect of mergers and acquisitions on the acquirer firm's financial performance used longer periods which is one year before the event day and two years after the event day [2], two years before the event day and two years after the event day [4][29] and three years before the event day and three years after the event day [15][18]. This shows that the period used in the study can affect the results of the study. In conducting mergers and acquisitions, it takes a long time to integrate with new companies to create synergies. Hence, it takes a longer time to accurately see the results and effects of these transactions [4][18][29].

The insignificant and positive effect on the acquirer firm's financial performance is consistent with previous research which found an insignificant and positive effect on the firm's financial performance which is measured using profitability ratios, liquidity ratios, and leverage ratios [21]. However, the findings in this study are different from previous studies which found a significant effect of Mergers and Acquisitions on the acquirer firm's financial performance, both positively [2][17] and negatively [4][15][18][19][29].

The results show that Firm Size, Firm Age, and Leverage have a negative effect on ROA. However, a negative and statistically significant effect could only be seen in Leverage The results show that after conducting merger and acquisition transactions, companies with great financial problems will obtain lower ROA [4] and be less profitable after the transaction [20].

\section{CONCLUSION}

This paper aims to analyze the impact of mergers and acquisitions on investor reaction and acquirer firm's financial performance on technology sector from firms in Asia. This research is conducted in the technology sector as the research on this sector is low compared to other sectors regarding the impact of merger and acquisition on investor reaction and acquirer firm's financial performance. Investor reaction is measured using Cumulative abnormal return (CAR) whereas the acquirer firm's financial performance is measured using Return on asset (ROA). The control variable used in this study is Firm Size, Firm Age, and Leverage. The result shows that mergers and acquisitions have a positive and statistically significant effect on investor reaction in the short term. This indicates that the merger and acquisition transaction could increase shareholder's wealth [5]. However, it could be seen that the positive effect on a firm's financial performance is insignificant. As the control variable: Firm Size, Firm Age, and Leverage are shown to have an insignificant effect on investor reaction. However, a significant and negative effect could only be seen on Leverage to the firm's financial performance.

This research can provide benefits for the management as this research could provide 
information regarding the impact of $\mathrm{M} \& \mathrm{~A}$ on investor reaction and a firm's financial performance. This study can be useful for the management in making corporate decisions and consider the objectives of conducting merger and acquisition transactions.

This study contributes to previous literature related to investor reaction and firm's performance especially in the technology sector which has not been supported sufficiently despite being a sector that's developing significantly and has a large amount of merger and acquisition transactions. This study can give an insight to other researchers regarding the investor reaction and firm's performance after the acquiring firm announces the merger and acquisition transactions.

Nonetheless, there are several limitations in this study that could lead to other research in the future. Investor reaction and firm's financial performance is an important aspect to measure the success of merger and acquisition transactions. However, both of them are not the only parameter to measure M\&A success. Thus, in the future, other studies could use other approaches or parameters to measure investor reaction and firm's financial performance. The period used to measure the firm's performance (1 year before and 1 year after the event day) may affect the result in this study. Therefore future studies may use a longer period as the effect of the transaction may be realized in the long term. The firm selected as a sample in this study is restricted to public companies due to the availability of the data on Bloomberg and Yahoo Finance. Thus, in the future, studies could include private firms as the sample. M\&A could increase a firm size, resources, and expand its market. Therefore, a firm must accurately forecast the positive impact gained as the investor reaction is influenced by the firm's prospect in the future after doing the M\&A transaction.

\section{AUTHORS' CONTRIBUTIONS}

This research was designed and conceptualized by $\mathrm{J}$, Y.K.A, and A. J, as the research supervisor, provided technical guidance. The data was acquired by A. The paper was written by Y.K.A and A. Y.K.A conducts the experiments, analyzes, and interprets the data.

\section{ACKNOWLEDGMENTS}

The authors would like to express deep gratitude to my research supervisor, Dr. Dra. Juniarti, M.Si., CA., CMA, for providing guidance and support throughout the research as the completion of this research could not have been accomplished without her. The authors would also express sincere gratitude to our family and friends for their encouragement and support throughout the entire process of this research.

\section{REFERENCES}

[1] M. Bianconi and C. M. Tan, "Evaluating the instantaneous and medium-run impact of mergers and acquisitions on firm values," Int. Rev. Econ. Financ., vol. 59, pp. 71-87, 2019, doi: http://dx.doi.org/10.2139/ssrn.295552.

[2] W. Zhang, K. Wan, Y. C. L. Li, and X. Wang, "The impact of firms mergers and acquisitions on their performance in emerging economies," Technol. Forecast. Soc. Change, vol. 135, pp. 208-216, 2018, doi: https://doi.org/10.1016/j.techfore.2018.05.015.

[3] C. Cheng and M. Yang, "Enhancing performance of cross-border mergers and acquisitions in developed markets: The role of business ties and technological innovation capability,” J. Bus. Res., vol. 81, pp. 107-117, 2017, doi: https://doi.org/10.1016/j.jbusres.2017.08.01.

[4] O. Bertrand and M.-A. Betschinger, "Performance of domestic and cross-border acquisitions: Empirical evidence from Russian acquirers," J. Comp. Econ., vol. 40 (3), pp. 413-437.

DOI: https://doi.org/10.1016/j.jce.2011.1, 2011, doi: https://doi.org/10.1016/j.jce.2011.11.003.

[5] F. Kiesel, J. M. Ries, and A. Tielmann, "The impact of mergers and acquisitions on shareholders' wealth in the logistics service industry," Int. J. Prod. Econ., vol. 193, pp. 781-797, 2017, doi: https://doi.org/10.1016/j.ijpe.2017.09.00.

[6] H. S. Bhabra and J. Huang, "An empirical investigation of mergers and acquisitions by Chinese listed companies 1997-2007," J. Multinatl. Financ. Manag., vol. 23(3), pp. 186207, 2013, doi http://dx.doi.org/10.1016/j.mulfin.2013.03.002

[7] D. Andriosopoulos, S. Yang, and W. Li, "The market valuation of M\&A announcements in the United Kingdom," Int. Rev. Financ. Anal., vol. 48, pp. 350-366, 2016, doi: https://doi.org/10.1016/j.irfa.2015.05.02.

[8] R. Ahmed, Y. Chen, C. Benjasak, A. Gregoriou, N. N. F. Alrwashdeh, and E. T. Than, "The performance of bidding companies in merger and acquisition deals: An empirical study of domestic acquisitions in Hong Kong and Mainland China," Q. Rev. Econ. Financ., 2020, doi: https://doi.org/10.1016/j.qref.2020.09.003. 
[9] A. R. Khanal, A. K. Mishra, and K. A. Mottaleb, "Impact of mergers and acquisitions on stock prices: The U.S. ethanol-based biofuel industry," Biomass, and Bioenergy, vol. 61, pp. 138-145, 2013, doi: https://doi.org/10.1016/j.biombioe.2013.12.004.

[10] E.Teti and S. Tului, "Do mergers and acquisitions create shareholder value in the infrastructure and utility sectors? Analysis of market perceptions," Util. Policy, vol. 64(10), p. 105, 2020, doi: http://dx.doi.org/10.1016/j.jup.2020.101053.

[11] E. Akben-Selcuk and A. Altiok-Yilmaz, "The Impact of Mergers and Acquisitions on Acquirer Performance: Evidence from Turkey," Bus. Econ. J., vol. 22, pp. 1-8, 2011.

[12] K. Edamura, S. Haneda, T. Inui, X. Tan, and Y. Todo, "Impact of Chinese cross-border outbound M\&As on firm performance: Econometric analysis using firm-level data," China Econ. Rev., vol. 30, pp. 169-179, 2014, doi: https://doi.org/10.1016/j.chieco.2014.06.011.

[13] Mohammed Bin Rashid Establishment, "The Role of Government in Supporting Entrepreneurship \& SME Development," Dubai, 2011.

[14] N. M. Leepsa and C. S. Mishra, "Post Merger Financial Performance: A Study with Reference to Select Manufacturing Companies in India," Int. Res. J. Financ. Econ., vol. 83, pp. 6-17.

[15] J. E. Farinós, B. Herrero, and M. A. Latorre, "Market valuation and acquiring firm performance in the short and long term: Out-of-sample evidence from Spain,” BRQ Bus. Res. Q., 2019, doi: http://dx.doi.org/10.1177/2340944420901048.

[16] R. Rao-Nicholson, J. Salaber, and T. H. Cao, "Longterm performance of mergers and acquisitions in ASEAN countrieS,” Res. Int. Bus. Financ., vol. 36, pp. 373-387, 2015, doi: https://doi.org/10.1016/j.ribaf.2015.09.024.

[17] A. Lakstutiene, J. Stankeviciene, R. Norvaisiene, and J. Narbutiene, "The Impact of Acquisitions on Corporate Performance Results During the Period of Economic Slowdown: Case of Lithuania," Procedia Soc. Behav. Sci., vol. 213, pp. 455-460, 2015, doi: http://dx.doi.org/10.1016/j.sbspro.2015.11.433.

[18] A. Rashid and N. Naeem, "Effects of mergers on corporate performance: An empirical evaluation using OLS and the empirical Bayesian methods," Borsa Istanbul Rev., vol. 17(1), pp. 10-24, 2017, doi: https://doi.org/10.1016/j.bir.2016.09.004.

[19] D. MacKinnon, Introduction to Statistical Mediation Analysis. 2012.
[20] S. S, "Measuring Post Merger Performance A Study of Metal Industry," Int. J. Appl. Res. Stud., vol. 2(8), 2013, doi: http://dx.doi.org/10.20908/ijars.v2i8.9463.

[21] I. S. Y1lmaz and B. Tanyeri, "Global Merger and Acquisition (M\&A) activity: 1992-2011," Financ. Res. Lett., vol. 17, pp. 110-117, 2016, doi:

https://doi.org/10.1016/J.FRL.2016.02.005.

[22] R. Bebenroth and M. Hemmert, "Countrylevel antecedents of target firms' postacquisition business performance: A study of inbound Japanese and Korean M\&As," Asian Bus. Manag., vol. 14 (4), 2015, doi: http://dx.doi.org/10.1057/abm.2015.10.

[23] M. Pervan, J. Višić, and K. Barnjak, "The Impact of M\&A on Company Performance: Evidence from Croatia," Procedia Econ. Financ., vol. 23, pp. 1451-1456, 2015, doi: https://doi.org/10.1016/S2212-5671(15)003512.

[24] Pemerintah Provinsi Bali, Peraturan Daerah No. 4 Tahun 2019 mengenai Desa Adat di Bali. 2019.

[25] S.-J. Chang and J. J. M. J. Chung, "When do foreign subsidiaries outperform local firms?," J. Int. Bus. Stud., vol. 44( 8), pp. 853-860, 2013, doi: http://dx.doi.org/10.1057/jibs.2013.35.

[26] A. A. Akolaa, "Foreign market entry through acquisition and firm financial performance," Int. J. Emerg. Mark., vol. 13(5), pp. 13481371, 2018, doi: http://dx.doi.org/10.1108/IJoEM-05-20170162.

[27] A. Rahman Inskandar, "Menguasai Pemrograman Berorientasi Objek," p. 349, 2020.

[28] E. Akben-Selcuk, "Do Mergers and Acquisitions Create Value for Turkish Target Firms? An Event Study Analysis," Procedia Econ. Financ., vol. 30, pp. 15-21, 2015, doi: http://dx.doi.org/10.1016/S22125671(15)01250-.

[29] A.Wong and K. Y. Cheung, "The Effects of Merger and Acquisition Announcements on the Security Prices of Bidding Firms and Target Firms in Asia," Int. J. Econ. Financ., vol. $1(2), \quad 2009, \quad$ doi: https://doi.org/10.1016/0304-405X(80)900148. 